\title{
Prediction and risk evaluation of chalk cliff collapse: the PROTECT project
}

\author{
Stig A. Schack Pedersen and Ingelise Møller
}

A major cliff collapse took place at Store Stejlebjerg in the southern part of Møns Klint on 5 July 2003 (Fig. 1). This cliff collapse was one in a number of rock falls that has affected Møns Klint with a frequency of about one per five years.

Geological investigations of the rock fall at Store Stejlebjerg were carried out by the Geological Survey of Denmark and Greenland (GEUS) after the Danish Forest and Nature Agency had asked for advice and help concerning security regulations for public access to the site. GEUS was prepared for this type of investigation due to the Survey's engagement in the European Union project PROTECT, which aims at prediction of chalk cliff collapses. In this project a number of sites in northern Europe have been selected for detailed investigation, among which two are situated at Møns Klint, southeast Denmark (Fig. 1). This report provides a short description of the 2003 cliff collapse at Møns Klint and a brief description of the PROTECT project and its practical implications for cliff collapse evaluation.

\section{The Store Stejlebjerg cliff collapse}

Møns Klint is a $4 \mathrm{~km}$ long N-S-trending coastal chalk cliff up to $130 \mathrm{~m}$ high bordering the east side of the island of Møn (Fig. 1). This cliff provides an instructive structural cross-section through a large glaciotectonic complex, the southern part of which can be characterised as an imbricate fan with thrust sheets consisting of $c .60 \mathrm{~m}$ upper Maastrichtian chalk overlain by $10-15 \mathrm{~m}$ glacial deposits of Weichselian age (Surlyk \& Håkansson 1999; Pedersen 2000). Store Stejlebjerg forms a nearly $90 \mathrm{~m}$ high vertical cliff section that prior to the rock fall had an irregular overhang from about $25 \mathrm{~m}$ up to about $70 \mathrm{~m}$ a.s.l. (Fig. 2). This overhang formed the basal boundary of the collapse unit, which is estimated to have a volume of $8000 \mathrm{~m}^{3}$. The large debris fans formed by the rock fall, constituted a southern $70 \mathrm{~m}$ long seawards projecting peninsula consisting of large blocks and a northern $90 \mathrm{~m}$ peninsula comprising finer-grained breccia (Fig. 3).

The site was reinvestigated in August 2003. No fractures were observed at the head of the rock fall, but fractures related to the syn-sedimentary slump deformation were seen in the lower part of the cliff with a direction parallel to the escarpment surface. Slickenside surfaces on some of the
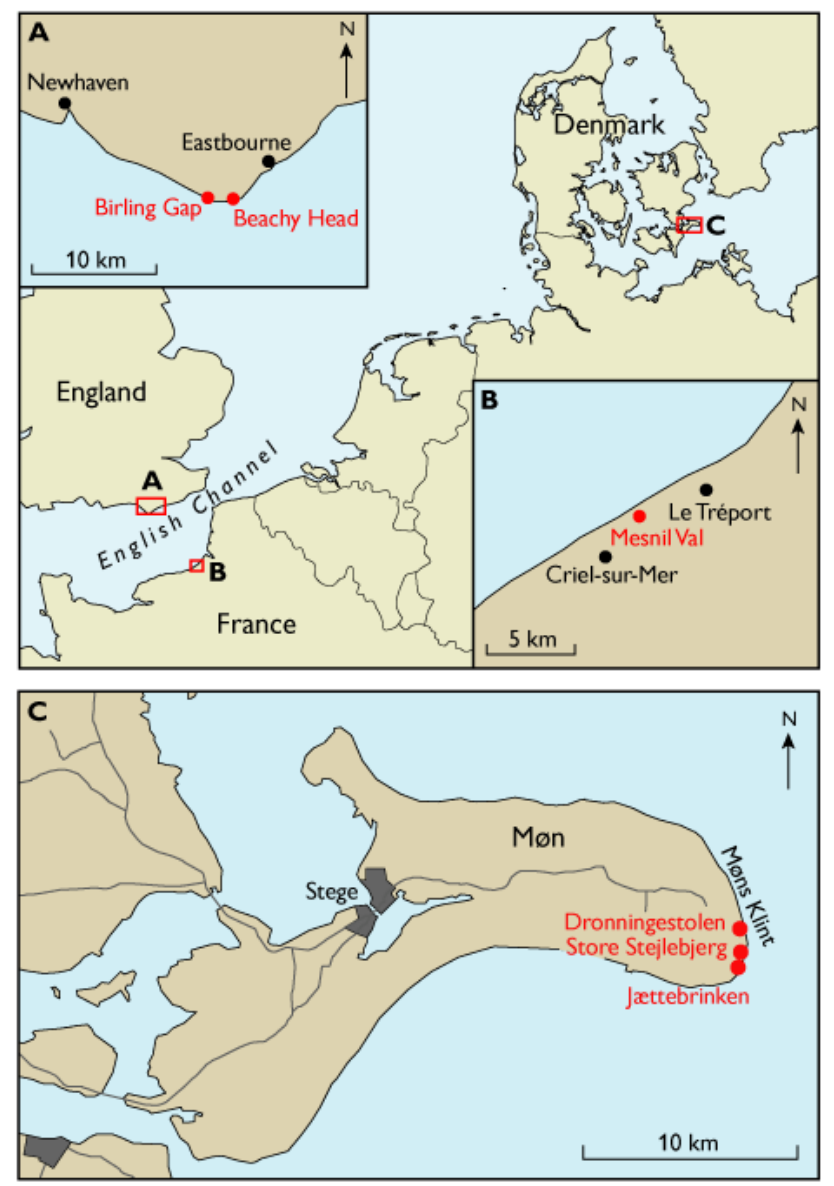

Fig. 1. Location map of the five test sites selected for the investigation of chalk cliff collapse in the EU-project PROTECT.

largest $\left(5 \mathrm{~m}^{3}\right)$ blocks indicated displacements along more than one fracture plane direction. The triggering of the rock fall was interpreted to be due to a very dry spring followed by heavy rainfall immediately preceding the cliff collapse.

\section{PROTECT}

The aims of the EU-project PROTECT (PRediction Of The Erosion of Cliffed Terrains), EU Contract No. EVK3-CT2000-00029, are to develop predictive tools that will identify sections of coastal chalk cliffs that are approaching a state of imminent collapse and allow accurate forecasts to be made concerning the timing of the collapse. The monitoring tools 


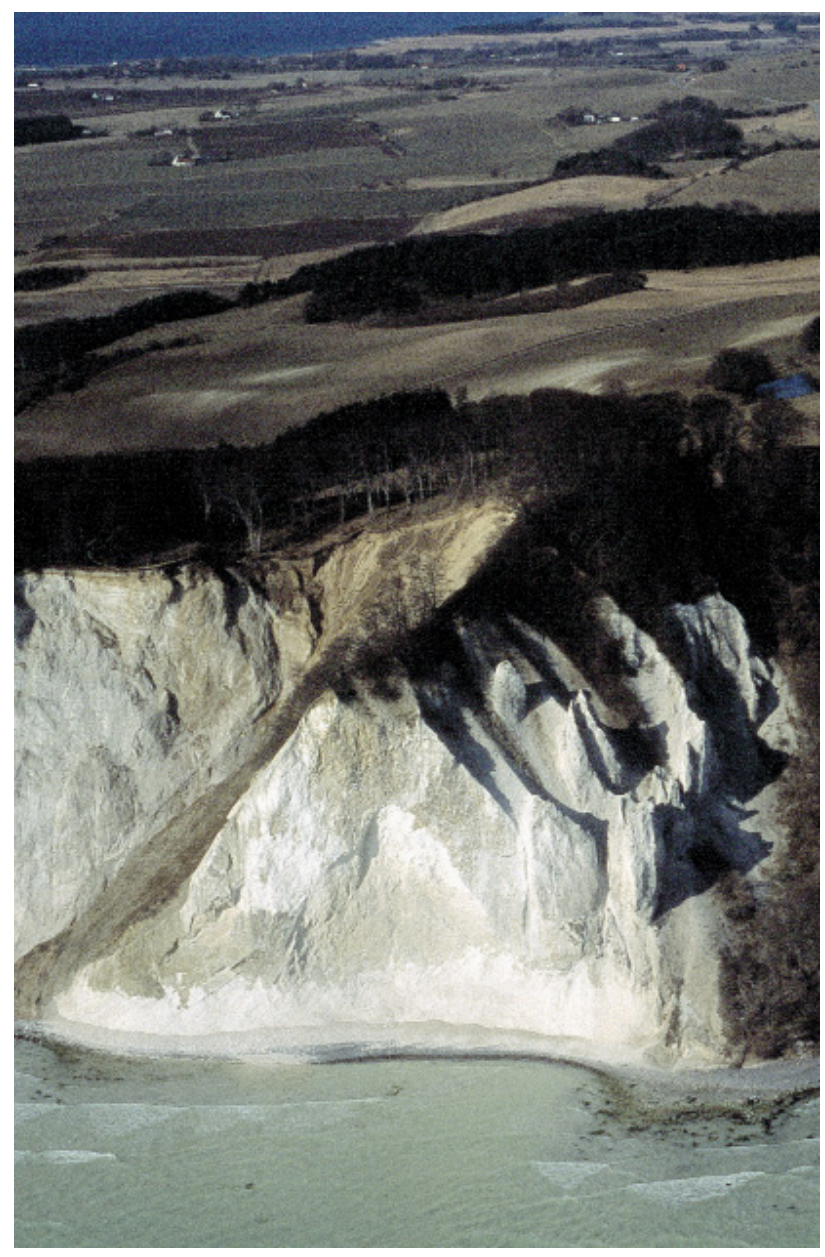

Fig. 2. Oblique aerial photograph of the $c .90 \mathrm{~m}$ high chalk cliff at Store Stejlebjerg prior to the rock fall. The photograph was taken on 13 March 2003 as part of a systematic photogrammetric survey aiming at an aerotriangulation of the Møns Klint cross-section for future examinations of structural geology and landslide activity.

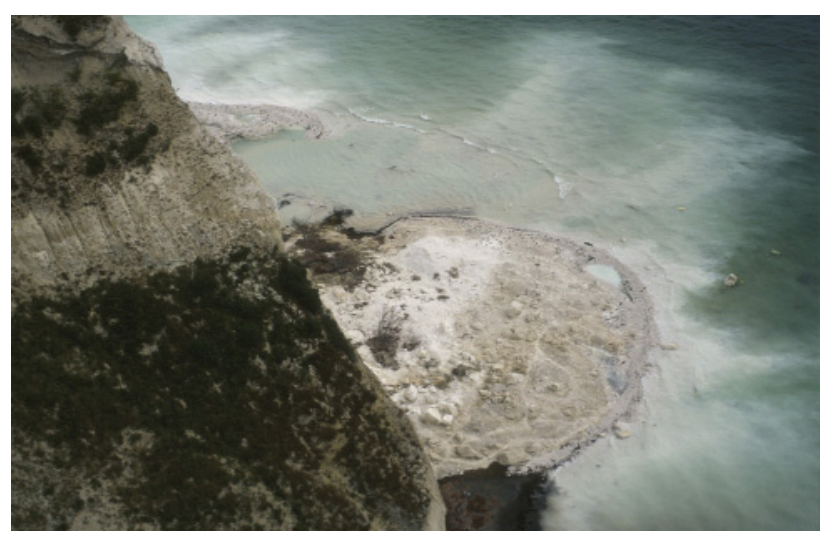

Fig. 3. The broad $90 \mathrm{~m}$ long peninsula formed by the rock fall seen from the top of Store Stejlebjerg on 29 August 2003. The preservation potential of these breccias is not high and the peninsula will probably be lost to erosion in about three years. focused on are azimuthal resistivity measurements, microseismicity and acoustic emission, and the project also aims at contributing to the understanding of the physical properties of rock masses which lead to unstable cliffs and failures. The project works closely with user communities in order to ensure that development is adapted to user requirements. This includes issuing informed hazard warnings in areas around cliffs, providing information for land-use planning in the coastal zone and conservation regulations, and maximising the use of the cliffed coastline as an amenity (Busby et al. 2002).

In the PROTECT project nine partners are involved: (1) British Geological Survey - project coordinator; (2) University of Brighton, England; (3) Bureau de Recherche Géologiques et Minières, France; (4) Geological Survey of Denmark and Greenland; (5) Institut National de l'environement Industriel et des Risques, France; (6) Isle of Wight Centre for the Coastal Environment, England; (7) Direction Departementale de l'Equipement de la Seine Maritime, France; (8) Urzad Morskiw Gdyni, Poland; and (9) Consorzio Ferrara Ricerche, Italy.

The main scientific topics addressed by the project are discussed below.

\section{Detection of fracture dilatancy}

Temporal azimuthal apparent resistivity measurements are made at the five research sites at bimonthly intervals (Figs 1, 4). The parameters required to monitor variations in the rock mass are determined and fracture orientations are calculated for each research site.

\section{Detection of cracking}

Five accelerometers and five geophones were installed at the test site in France (Mesnil Val; Fig. 1) and acquisition began in January 2002. Initial investigations of the microseismic activity shows that a microseismic event can be recorded on one transducer. As a consequence, the microseismic network is strongly recommended compared to the waveguide system, which has also been considered (Busby et al. 2002).

\section{Influence of rock and external parameters}

Detailed rock mass data and erosion data are collected from the research sites, and rock sampling for investigation of physical properties and strength of the chalk is carried out. Meteorological and water level data, including external temperature, barometric pressure, wind velocity and direction, and precipitation are recorded for the study of influence of external parameters on the behaviour of the rock mass. 


\section{Beachy Head}

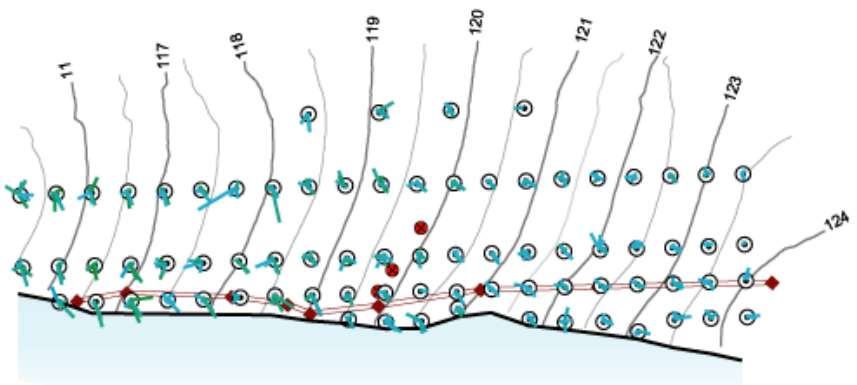

Birling Gap
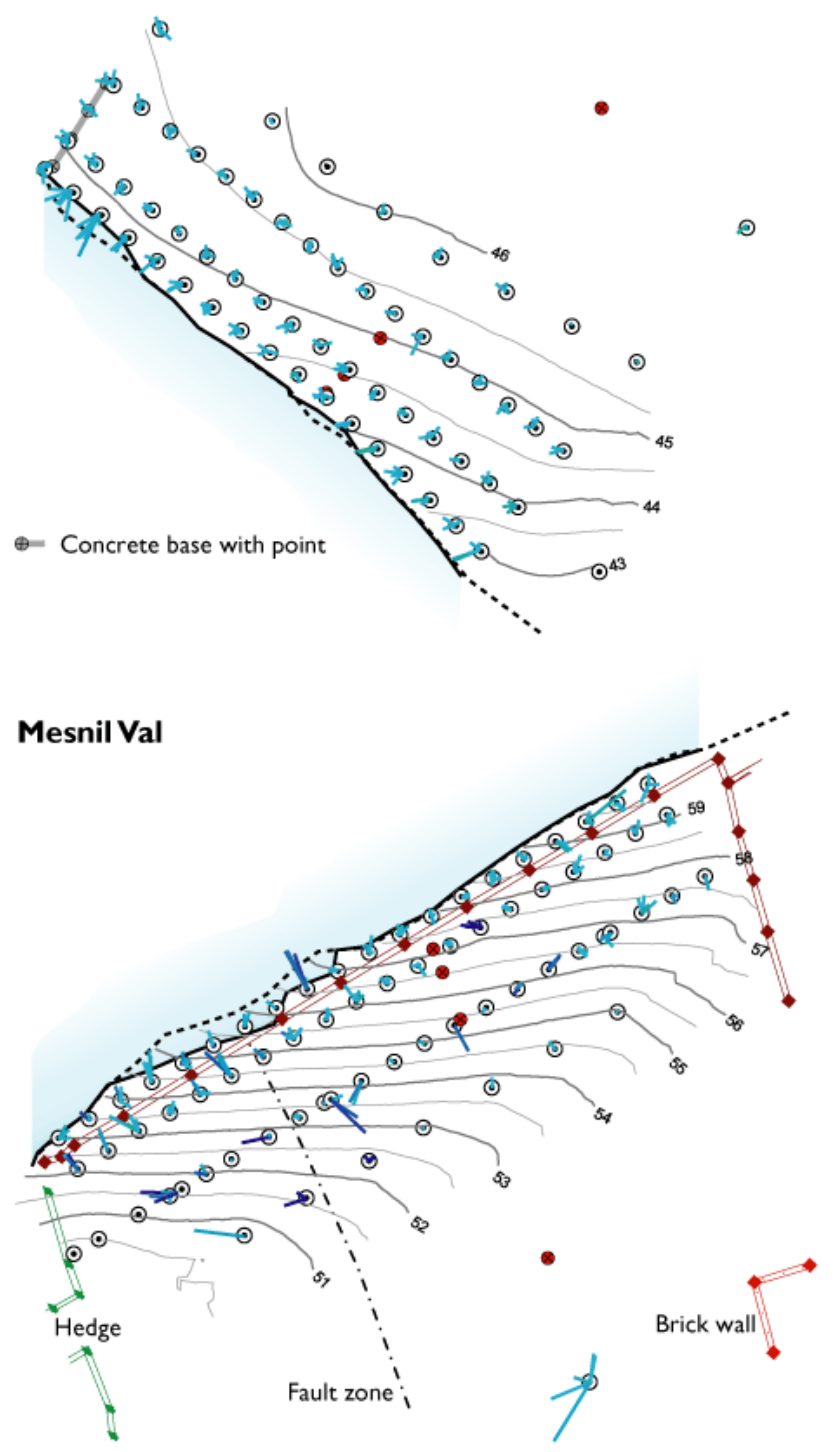

Dronningestolen

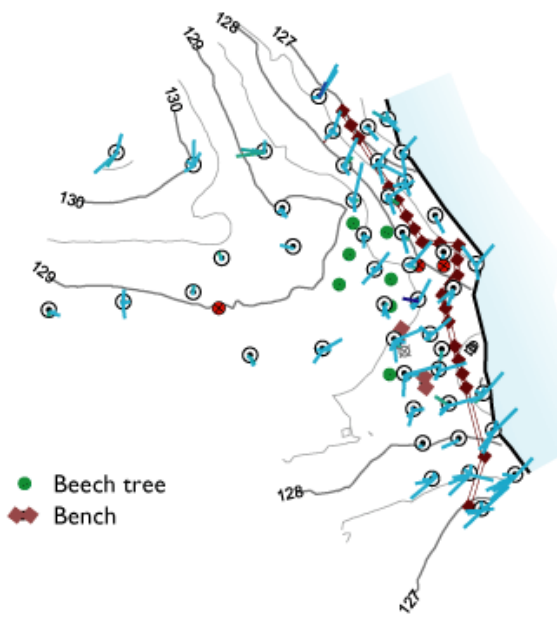

\section{Jættebrinken}

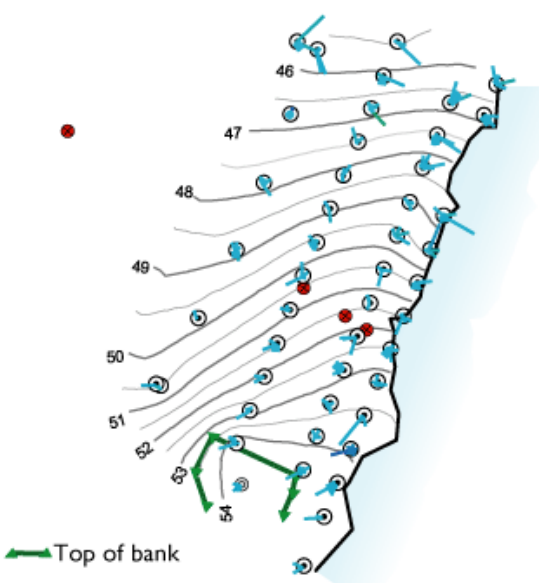

- Azimuthal apparent resistivity point

○ Measurement point

- Present cliff edge

..- Cliff edge at first measurement campaign

* Fence

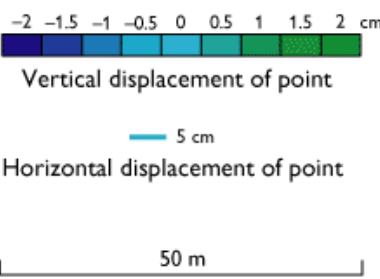

Fig. 4. Maps of the five test sites established for the PROTECT investigations. All locality maps drawn with north at top. Contour lines are in metres. Each grid point is provided with a vector bar representing the displacement of the grid point based on repeated measurements. The displacement is relative to the first measurement. Horizontal displacements shown by length of bar (upscaled by a factor of 100). Vertical displacments are shown by colour. 


\section{Interpretation and integration of data}

A database has been established for the data sets collected by the PROTECT project. All surveys of fracturing and rock strength are stored for comparison and integrated interpretation. A rock fall at the French site in June 2002 destroyed all the connecting wires and conductors installed in January, and had to be replaced. However, the signal obtained from this rock fall gave a very marked precursor anomaly, which indicated that the collapse could be predicted about eight hours before it happened.

During the first project period a monitoring system for direct verification of precursor movements in the terrains or actual collapse of the cliff was established. Five field sites were selected for the investigations: two at Møns Klint in Denmark (Jættebrinken and Dronningestolen), two sites at Eastbourne on the south coast of England (Beachy Head and Birling Gap), and one site at the French coast in Normandy (Mesnil Val; Fig. 1). Subsequent reporting from the monitoring system has been submitted regularly, and measurements of the test grids established in the field have been carried out at an interval of about 4 months.

For testing the dislocations in the terrain a grid has been established at each research field (e.g. Fig. 4). The grid consists of a number of fixed points that have been measured with a theodolite. In general the deviation of the measurements is within $\pm 1 \mathrm{~cm}$ on the $z$-coordinate. The $x$ and $y$ coordinates have a somewhat larger deviation, which is mostly below $\pm 3 \mathrm{~cm}$ (Pedersen et al. 2002). One of the results from the test grid measurements is that the volume involved in the collapse at Mesnil Val in June 2002 could be calculated to $2750 \mathrm{~m}^{3}$. Moreover, it is evident that initial creep along the fault zone displacing the Birling Gap field has been documented by the test grid measurements (Fig. 4).

\section{Prediction and risk evaluation of landslides and rock falls}

In order to predict rock falls the sites for potential collapse must be identified and the triggering mechanism has to be understood. The sites with most potential for collapse are of course overhanging cliffs; however, some of the collapses are also related to older fault and fracture systems, which demand a structural analysis to provide a structural model for prediction of risky sites. GEUS will continue its mapping of Møns Klint, and when the potential sites for collapse have been identified it will be possible to install monitoring equipment for collapse warning. The experiences from PROTECT suggest that acoustic emission is a promising tool, and the Survey intends to continue cooperation for developing improved prediction equipment.

Considering the risk evaluation, one evaluation parameter is the past frequency of rock falls. The record of landslides at Møns Klint over the last 100 years indicates that a major landslide or rock fall will occur about every fifth year (Pedersen 2003). Another parameter could be to estimate the erosion rate. At Møns Klint the erosion rate varies from zero at Jættebrinken to nearly $50 \mathrm{~cm}$ per year north of Dronningestolen (Pedersen 2003). The average erosion rate is about 35 $\mathrm{cm}$ per year, which is relatively small compared to the erosion rate of about $70 \mathrm{~cm}$ per year along the English Channel (data from the PROTECT data files). In spring 2003, GEUS was asked to provide a landslide risk analysis for a projected exhibition centre at Møns Klint. Based on a structural model for the location of the centre and the erosion rate estimates the main conclusion was that the centre would not be threatened by coastal landslide erosion in the foreseeable future (Pedersen 2003).

\section{References}

Busby, J.P., Gourry, J.C., Senfaute, G., Pedersen, S. \& Mortimore, R. 2002 Can we predict coastal cliff failure with remote, indirect measurements. In: McInnes, R. \& Jakeways, J. (eds): Instability, planning and management, 203-208. London: Thomas Telford.

Pedersen, S.A.S. 2000: Superimposed deformation in glaciotectonics. Bulletin of the Geological Society of Denmark 46, 125-144.

Pedersen, S.A.S. 2003: Vurdering af skredrisiko for området oven for Maglevandsfaldet på Møns Klint. Danmarks og Grønlands Geologiske Undersøgelse Rapport 2003/50, 35 pp.

Pedersen, S.A.S., Møller, I. \& Gudmunsson, L. 2002: Test grid established for the EU-project PROTECT at cliffed terrains in Denmark, England and France. Danmarks og Grønlands Geologiske Undersøgelse Rapport 2002/30, 30 pp.

Surlyk, F. \& Håkansson, E. 1999: Maastrichtian and Danian strata in the southeastern part of the Danish Basin. In: Pedersen, G.K. \& Clemmensen, L.B. (eds): Field trip guide for 19th Regional European Meeting of Sedimentology (August 1999), 29-58. Copenhagen: IAS.

\footnotetext{
Authors' address

Geological Survey of Denmark and Greenland, Øster Voldgade 10, DK-1350 Copenhagen K, Denmark. E-mail: sasp@geus.dk
} 